\title{
ZMĚNY V MOTORICKÉ VÝKONNOSTI CHLAPCŮ VE VĚKU 11-15 LET MEZI ŠKOLNÍMI ROKY 1996/1997 - 2018/2019
}

\author{
Klára Kuprová $^{1}$; Martina Ježková ${ }^{2}$; Jaroslav Kupr ${ }^{3}$; Josef Čapek ${ }^{4}$; Václav Bittner \\ 1,2,3,5 Technická univerzita v Liberci, \\ Fakulta přírodovědně-humanitní a pedagogická, Katedra tělesné výchovy, \\ Studentská 1402/2, 46117 Liberec 1, Česká republika \\ ${ }^{4}$ Základní škola T. G. Masaryka Lomnice nad Popelkou, \\ Školní náměstí 1000, 51251 Lomnice nad Popelkou, Česká republika \\ e-mail: ${ }^{1}$ klara.kuprova@tul.cz; ${ }^{2}$ martina.jezkova@tul.cz; ${ }^{3}$ jaroslav.kupr@tul.cz; \\ capekj@zstgmlomnice.cz; ${ }^{4}$ vaclav.bittner@tul.cz
}

\begin{abstract}
Abstrakt
Studie vyhodnocuje změny v motorické výkonnosti u chlapců staršího školního věku na základní škole v Lomnici nad Popelkou.

Vývoj motorické výkonnosti je sledován u chlapců ve věku 11-15 let z nesportovních tříd na základě neformální testové baterie šesti motorických testů (běh na $60 \mathrm{~m}$, běh na $1000 \mathrm{~m}$, sedleh opakovaně, skok daleký, trojskok snožmo z místa, shyb opakovaně) v časovém úseku dvaceti dvou let (školní roky 1996/1997 - 2018/2019). Celkově se motorického testování účastnilo 1863 chlapců ve všech věkových kategoriích. Výsledky poukazují na nezměněnou až klesající úroveň motorické výkonnosti v průběhu evidovaného časového období u většiny použitých testů u všech věkových skupin.
\end{abstract}

\section{Keywords}

Boys; Motoric tests; Motoric performance; Primary education age; Physical education.

\section{Abstrakt}

Studie vyhodnocuje změny v motorické výkonnosti u chlapců staršího školního věku na základní škole v Lomnici nad Popelkou.

Vývoj motorické výkonnosti je sledován u chlapců ve věku 11-15 let z nesportovních tříd na základě neformální testové baterie šesti motorických testů (běh na $60 \mathrm{~m}$, běh na $1000 \mathrm{~m}$, sedleh opakovaně, skok daleký, trojskok snožmo z místa, shyb opakovaně) v časovém úseku dvaceti dvou let (školní roky 1996/1997 - 2018/2019). Celkově se motorického testování účastnilo 1863 chlapců ve všech věkových kategoriích. Výsledky poukazují na nezměněnou až klesající úroveň motorické výkonnosti v průběhu evidovaného časového období u většiny použitých testů u všech věkových skupin.

\section{Úvod}

Za poslední desetiletí až století se změnilo chování lidské společnosti. Změny jsou ovlivněny převážně technickým pokrokem, který změnil nejenom způsob stravování, dopravy, zdravotní péče, ale i náplň volného času lidí. Dnešní doba se vyznačuje neustálým spěchem, ve kterém dospělí bývají často inaktivní a tak ani své děti nevedou k pohybové aktivitě. Děti tráví volný čas u počítačů a mobilních telefonů. Tento druh komunikace začíná pomalu převažovat nad osobní komunikací a umožňuje dětem mít společnost vrstevníků a zábavy z pohodlí domova 
bez minimální pohybové aktivity. Přitom pohybová aktivita, trénovanost, tělesné složení, dědičnost, biologický věk, pohlaví a motivace ovlivňuje tělesnou zdatnost a tím i zdraví jedince [32]. Jedinec tělesně zdatný, vykonává každodenní běžné úkoly aktivně, účelně využívá svůj volný čas a je odolný vůči stresu [2]. Tělesná zdatnost a její psychické prožívání má velký význam pro zdravé utváření dětské osobnosti. Dobré zdraví a náležitá tělesná zdatnost mají z psychologického hlediska velikou hodnotu [18]. Rubín a kol. [30] uvádí, že v rámci tělovýchovné praxe by mělo být hodnocení tělesné zdatnosti nedílnou součástí celého vyučovacího procesu. Pedagogové by měli podporovat spíše pohybové chování než pouze dosahování vysoké úrovně motorické výkonnosti. Tělesná zdatnost je důležitým cílem, ale z celoživotního hlediska je prrínosnější pozitivní přístup k pravidelné pohybové aktivitě.

Při hodnocení tělesné zdatnosti dětí i dospělých má svoje opodstatnění posuzování aktuální úrovně i vývojových změn jedince. Důležitým prvkem tělesné zdatnosti člověka je základní motorická výkonnost, kterou považujeme za hlavní ukazatel pohybové výkonnosti člověka. Jedná se o dlouhodobý proces směřující $\mathrm{k}$ všestrannému tělesnému rozvoji. Cílem není vrcholový výkon. Jedinec s dobrou úrovní základní motorické výkonnosti se rychle adaptuje na zátěž, následně se rychle zotavuje a nedochází k nepřiměřené únavě. O motorické výkonnosti na odpovídající úrovni mluvíme v okamžiku rozvinutí základních pohybových schopností a dovedností $[5,13,32,21]$. V praxi naráźíme na pojem motorická výkonnost. Adaptace na ní je specifičtější než u základní motorické výkonnosti. Jedinec je tedy schopen podávat velmi dobré výkony v určité vymezené pohybové činnosti [32].

Motorickou výkonnost lze otestovat prostřednictvím testových baterií. Baterie se skládá z několika dílčích testů [17]. Měkota a Blahuš [21] dělí testy na standardizované a neformální. Standardizované testy jsou vyzkoušené a především vědecky a statisticky prozkoumané. Mezi nejznámější testové baterie u nás lze zařadit EUROFIT, UNIFITTEST, FITNESSGRAM, INDARES, a Odznak všestrannosti $[9,6,26,8,11,31]$. Neformální testy nedosahují tak vysoké kvality, ale přizpůsobí se individuálním možnostem [21]. Neformální testy nebývají finančně a organizačně náročné.

Měkota a Blahuš [21] dělí testové baterie na homogenní a heterogenní:

a) Homogenní: účelem je zvýšit reliabilitu. Všechny testy si jsou navzájem podobné a testují jednu motorickou schopnost.

b) Heterogenní: účelem, je zvýšit validitu testu. Skládají se z různorodých testů tak, aby byla otestována fyzická zdatnost a kondice.

Motorické testy můžeme $\mathrm{z}$ hlediska realizace dělit na laboratorní a terénní. Terénní testy jsou v praxi nejrozšsiřenějším způsobem hodnocení [31,32]. Motorické testy jsou dnes součástí přijímacích řízení do škol, ale i do různých profesí (vojáci, hasiči, policisté apod.). K testování vrcholových sportovců se dnes běžně využívají sportovní laboratoře. Stále častěji jsou také pro běžnou populaci dostupné testy, které nejsou materiálně a časově náročné. Jejich cílem je motivace obyvatel k pravidelnému cvičení a zdravějšímu životnímu stylu [12].

Ve školním prostředí vyučující tělesné výchovy často používají neformální heterogenní baterii testů. Výsledky z těchto testů jim často slouží jako jedno z hodnotících kritérií prospěchu z předmětu tělesná výchova.

\section{$1 \quad$ Cíl studie}

Cílem studie bylo sledovat motorické výkony pomocí neformální testové baterie a vyhodnotit vývoj motorické výkonnosti chlapců staršího školního věku na základní škole v Lomnici nad Popelkou. 


\subsection{Charakteristika souboru}

Výzkumný soubor tvořilo $\mathrm{N}=1863$ chlapců ve věku 11-15 let. Všichni byli žáky nesportovních tříd Základní školy T. G. Masaryka v Lomnici nad Popelkou a to v rozmezí školních let 1996/1997 až 2018/2019. V každém ročníku byly dvě paralelní třídy. Výzkumný soubor byl pro účely této studie rozdělen do pěti věkových a šesti časových (podle školních ročníků) kategorií (viz Tab. 1).

Tab. 1: Kontingenční tabulka rozložení věku žáků v závislosti na školních ročnících

\begin{tabular}{|c|c|c|c|c|c|c|c|}
\hline $\begin{array}{l}\text { Věk / } \\
\text { Ročník }\end{array}$ & $\begin{array}{l}1996 / 1997 \\
-1999 / 2000\end{array}$ & $\begin{array}{l}2000 / 2001 \\
-2003 / 2004\end{array}$ & $\begin{array}{l}2004 / 2005 \\
-2007 / 2008\end{array}$ & $\begin{array}{l}2008 / 2009 \\
-2011 / 2012\end{array}$ & $\begin{array}{l}2012 / 2013 \\
-2015 / 2016\end{array}$ & $\begin{array}{l}\text { 2016/2017 } \\
-2018 / 2019\end{array}$ & $\Sigma$ \\
\hline 11 let & 66 & 71 & 63 & 44 & 43 & 34 & 321 \\
\hline 12 let & 99 & 90 & 89 & 74 & 57 & 39 & 448 \\
\hline 13 let & 94 & 95 & 87 & 79 & 56 & 40 & 451 \\
\hline 14 let & 92 & 96 & 68 & 84 & 63 & 33 & 436 \\
\hline 15 let & 35 & 35 & 33 & 34 & 37 & 33 & 207 \\
\hline$\Sigma$ & 386 & 387 & 340 & 315 & 256 & 179 & 1863 \\
\hline
\end{tabular}

Zdroj: Vlastní

\subsection{Charakteristika výzkumných metod}

Použitá testová baterie vznikla na základě výběru a uvážení vyučujícího tělesné výchovy ve školním roce 1996/1997. Vybraných šest motorických testů tvoří nespecifickou heterogenní testovou baterii, která generuje kontinuální výsledky z 22 školních let. Baterie není nikde uveřejněna, a není tedy nijak standardizována. Terénní realizaci umožňuje standardní školní prostředí (atletické hřiště, školní tělocvična). Testová baterie obsahuje šest motorických testů - běh na 60 m, běh na 1000 m, sed-leh opakovaně, skok daleký, trojskok snožmo z místa, shyby opakovaně. Baterie neobsahuje zjišt'ování somatické charakteristiky probandů.

\subsection{Podmínky a realizace testování}

Testování pro celé časové období prováděl vyučující Mgr. Josef Čapek. Pro všechny roky (1996/1997-2018/2019) využíval jednotných metodických postupů v reálném prostředí základní školy v Lomnici nad Popelkou. Žáci znali didaktické postupy, měli možnost nácviku motorických testů (správného provedení). Testování bylo vždy prováděno v jarních měsících (březen-květen) $\mathrm{v}$ daném školním roce. Žádný ze sledovaných roků nebyl něčím zásadním odlišný od ostatních.

\section{$2.4 \quad$ Realizace vybraných motorických testů}

\subsubsection{Běh na $60 \mathrm{~m}$}

Provedení: startují dvě testované osoby najednou z nízkého startu, z bloků. Na startovní povel vyběhnou směrem k cíli. Tretry nejsou povoleny. Test se vykonává jedenkrát. Vyučující měří čas stopkami s přesností na jednu desetinu.

\subsubsection{Běh na $1000 \mathrm{~m}$}

Provedení: probandi jsou rozřazeni do skupin dle chronologického věku. Startuje celá skupina najednou z vysokého startu. Na startovní povel vyběhnou směrem k cíli. Tretry nejsou povoleny. Test se vykonává jedenkrát. Vyučující měři čas stopkami s přesností na jednu sekundu. 


\subsubsection{Sed-leh opakovaně}

Provedení: testované děti zaujmou polohu vleže, kolena svírají pravý úhel, chodidla jsou od sebe vzdálená $30 \mathrm{~cm}$, paže pokrčené ve vzpažení a ruce spojené za hlavou. Opakovaně vykonávají z výchozí polohy leh-sed co nejrychleji v průběhu 1 minuty. Test se vykonává jedenkrát.

\subsubsection{Skok daleký}

Provedení: testovaný jedinec provede skok daleký s rozběhem z rozběhové dráhy odrazem jednonož. Započítáváme nejlepší ze třech pokusů a výsledky uvádíme s přesností na $1 \mathrm{~cm}$.

\subsubsection{Trojskok snožmo z místa}

Provedení: ze stoje mírně rozkročného těsně před odrazovou čarou (chodidla rovnoběžně, přibližně v šíři ramen) provedou testované děti podřep a předklon, zapaží a odrazem snožmo se současným švihem paží vpřed skočí plynule třikrát za sebou co nejdále. Přípravné pohyby paží a trupu jsou dovoleny, není však povoleno poskočení před odrazem. Započítáme nejlepší ze dvou pokusů a výsledky uvádíme s přesností na $1 \mathrm{~cm}$.

\subsubsection{Shyb opakovaně}

Provedení: testovaný jedinec chytí hrazdu nadhmatem a z klidného svisu provádí plynule opakovaně shyby (dolní okraj brady musí být nad žerdí). Po každém shybu se musí začínat další shyb z výchozí polohy. Není dovoleno trčení nohama, komíhání ani výdrž ve svisu delší než 1 sekundu. Test končí v okamžiku, kdy se testovaný jedinec po shybu nenavrátí do úplného svisu a také když shyb nedokončí. Test se provádí jedenkrát.

\subsection{Metody zpracování dat}

V rámci statistického zpracování dat byl využit aritmetický průměr jako ukazatel centrální polohy a směrodatná odchylka jako ukazatel rozptylu. K posouzení statistické významnosti vlivu školního ročníku na úroveň motorických schopností ve stejné věkové kategorii byla použita parametrická ANOVA (shodnost rozptylů dat byla ověřena Levenerovým a BrownForsytheovým testem). Hladina statistické významnosti byla zvolena $\alpha=0.05$. Pro přehlednost jsou výsledky statistických testů vyjádřeny $\mathrm{v}$ dosažené hladině statistické významnosti tzv. $p$-value $(p)$. K vyhodnocení míry efektu byla zvolena následující škála: $p>$ 0.05 žádný efekt, $0.05 \geq p>0.01$ malý efekt, $0.01 \geq p>0.001$ střední efekt, $p \leq 0.001$ velký efekt. Dále byla posouzena věcná významnost rozdílu mezi sledovanými soubory a to s pomocí Cohenova $d$. Míra efektu byla hodnocena podle Cohena [7] $d<0.02$ žádný efekt, $0.02 \geq d>0.5$ malý efekt, $0.5 \geq d>0.8$ střední efekt, $d \geq 0.8$ velký efekt. Ke zhodnocení trendu vývoje úrovně motorických schopností byly využity následující ukazatele.

Těsnost vztahu mezi kategoriemi školních ročníků a výkonem v dané věkové skupině byla zkoumána Pearsonovým korelačním koeficientem $r$. Tvar trendové závislosti těchto dvou znaků byl následně popsán regresním modelem. Vzhledem k pouze šesti uzlovým bodům byla aproximační funkce volena jako polynom prvního až maximálně třetího řádu. Kvalita modelu je v grafech popsána koeficientem determinace $R^{2}$. Rozhodujícím kritériem pro volbu řádu polynomu byl požadavek, aby vyšší řád polynomu vylepšil aproximaci polynomem nižšího řádu minimálně o $\Delta R^{2}=0.5$. V rámci provedených korelačních i regresních výpočtů bylo nutné stanovit souřadnice datových bodů. Na časové ose byly využity středy jednotlivých kategorií školních ročníků (konkrétně roky 1998, 2002, 2006, 2010, 2014, 2017.5), výkony $\mathrm{v}$ daném motorickém testu byly popsány aritmetickým průměrem výkonů všech jedinců 
$\mathrm{v}$ dané věkové skupině a $\mathrm{v}$ př́slušné kategorii školních ročníků. Data byla zpracována s využitím SW nástrojů Statistica a MS Excel.

\subsection{Unikátnost výsledků}

Unikátnost studie spočívá v dlouhodobé práci Josefa Čapka na dané základní škole a v jeho schopnosti pravidelného testování žáků a evidenci získaných dat. Časové období školních let 1996/1997-2018/2019 (22 let) je dostatečně dlouhým časovým úsekem, který poskytuje zpětný pohled na problematiku. Zvolená testová baterie není nikterak standardizovaná, ale i tak poskytuje zajímavý vhled do testovaného období. Celkový počet probandů (1863) je také velmi hodnotným číslem.

\section{$3 \quad$ Výsledky}

Výsledky naší studie zachycují vývojové trendy (viz obr. 1-6) motorické výkonnosti 1115letých chlapců z Lomnice nad Popelkou. Pro správnou interpretaci výsledků uvádíme testy statistické a věcné významnosti rozdílů mezi školními ročníky chlapců (viz tab. 2).

Tab. 2: Analýza vlivu školního ročníku na stav vybraných komponent motorických schopností chlapců ve věkových kategoriich $11-15$ let

\begin{tabular}{|c|c|c|c|c|c|c|c|c|c|c|c|c|}
\hline \multirow[b]{2}{*}{ Věk } & \multicolumn{2}{|c|}{ Běh na $60 \mathrm{~m}$} & \multicolumn{2}{|c|}{ Běh na 1000 m } & \multicolumn{2}{|c|}{ Sed - leh } & \multicolumn{2}{|c|}{ Skok daleký } & \multicolumn{2}{|c|}{ Trojskok } & \multicolumn{2}{|c|}{ Shyby } \\
\hline & $p$ & $\begin{array}{l}\bar{d} \\
/ d_{\max }\end{array}$ & $p$ & \begin{tabular}{|l|}
$\bar{d}$ \\
$/ d_{\max }$
\end{tabular} & $p$ & $\begin{array}{l}\bar{d} \\
/ d_{\max }\end{array}$ & $p$ & \begin{tabular}{|l|}
$\bar{d}$ \\
$/ d_{\max }$
\end{tabular} & $p$ & \begin{tabular}{|l|}
$\bar{d}$ \\
$/ d_{\max }$ \\
\end{tabular} & $p$ & $\begin{array}{l}\bar{d} \\
/ d_{\max }\end{array}$ \\
\hline 11 let & 0.40 & $0.21 / 0.45$ & 0.07 & $0.34 / 0.66$ & 0.02 & $0.50 / 1.11$ & 0.29 & $0.22 / 0.50$ & 0.04 & $0.39 / 0.83$ & 0.99 & $0.05 / 0.10$ \\
\hline 12 let & 0.56 & $0.16 / 0.36$ & 0.12 & $0.24 / 0.53$ & $<0.01$ & $0.70 / 1.47$ & 0.03 & $0.31 / \underline{0.78}$ & 0.54 & $0.13 / 0.35$ & 0.23 & $0.22 / 0.43$ \\
\hline 13 let & 0.40 & $0.17 / 0.32$ & 0.14 & $0.23 / 0.53$ & 0.01 & $0.41 / 0.90$ & 0.23 & $0.20 / 0.38$ & 0.91 & $0.10 / 0.22$ & 0.40 & $0.19 / 0.46$ \\
\hline 14 let & 0.13 & $0.21 / 0.50$ & 0.11 & $0.25 / 0.48$ & 0.04 & $0.33 / 0.63$ & 0.17 & $0.20 / 0.46$ & 0.40 & $0.15 / 0.35$ & 0.36 & $0.22 / 0.52$ \\
\hline 15 let & 0.26 & $0.29 / 0.64$ & 0.20 & $0.30 / 0.72$ & 0.34 & $0.27 / 0.55$ & 0.11 & $0.40 / 1.01$ & $\underline{0.06}$ & $0.44 / 1.04$ & 0.10 & $0.39 / 0.85$ \\
\hline
\end{tabular}

Legenda: $p$-value - míra efektu ,školní ročník“ (ANOVA), $\bar{d} / d_{\max }$ - průměrné / maximální Cohenovo $d$.

Poznámka: Vzhledem k šesti kategoriím školních ročníků existuje pro každou věkovou kategorii a každý sledovaný parametr vždy 15 možných dvojic souborů, které lze vzájemně srovnat. Kvưli Zdroj: Vlastni přehlednosti je tak vždy uveden průměr a maximum $\mathrm{z}$ těchto hodnot.

\subsection{Běh na $60 \mathrm{~m}$}

V motorickém testu běh na 60 m indikátoru běžecké rychlostní schopnosti je patrné zlepšení s ohledem na narůstající chronologický věk v průběhu celého sledovaného období (viz Obr. 1 - Fig. 1). Výraznější zlepšení výkonnosti je možné pozorovat mezi dvanáctiletými a třináctiletými chlapci do roku 2016 a mezi třináctiletými a čtrnáctiletými chlapci po roce 2016. 


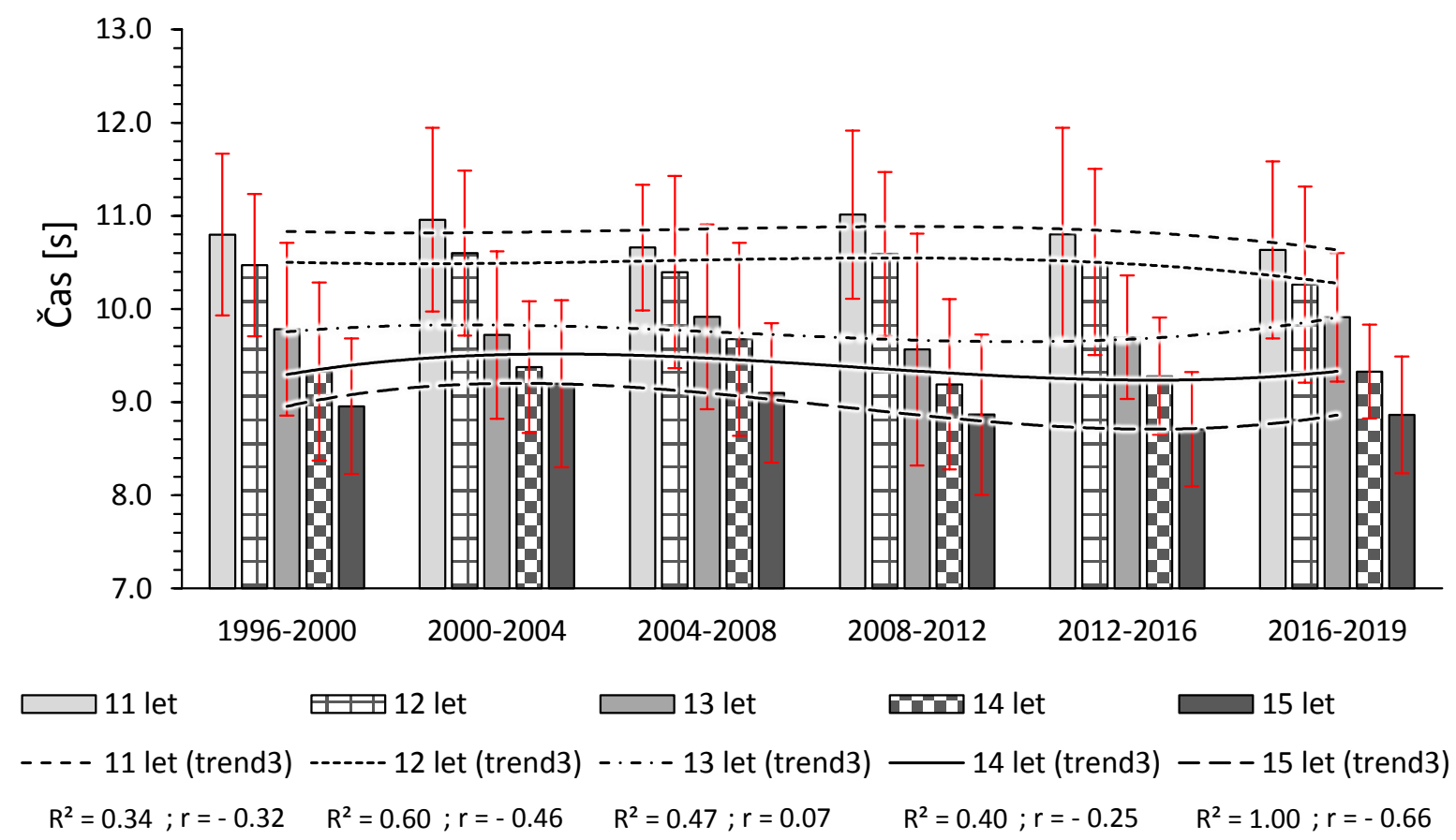

Legenda: Chybové úsečky představují interval hodnot aritmetický průměr \pm směrodatná odchylka.

trend3 regresní závislost vyjádřená polynomem 3. řádu

$R^{2} \quad$ koeficient determinace regresního modelu

$r \quad$ Pearsonův korelační koeficient (těsnost vztahu mezi školním ročníkem a výkonem v dané věkové

Zdroj: Vlastni skupině)

Fig. 1: Běh na 60 m-vývoj běžecké rychlostní schopnosti

$\mathrm{Z}$ analýzy výkonů v motorickém testu běh na $60 \mathrm{~m}$ jsme zaznamenali na základě Pearsonova korelačního koeficientu nulový trend vývoje výkonnosti v běžecké střednědobé vytrvalostní schopnosti u všech věkových kategorií chlapců. Tento trend potvrzuje i statistická a věcná významnost rozdílu hodnot (viz Tab. 2).

\subsection{Běh na $1000 \mathrm{~m}$}

V motorickém testu běh na $1000 \mathrm{~m}$ indikátoru běžecké střednědobé vytrvalostní schopnosti je patrné zlepšení s ohledem na narůstající chronologický věk v průběhu celého sledovaného období (viz Obr. 2 - Fig. 2). Výraznější zlepšení výkonnosti je možné pozorovat mezi jedenáctiletými a dvanáctiletými chlapci. Stagnaci růstu výkonnosti pozorujeme u chlapců od 13 let. 


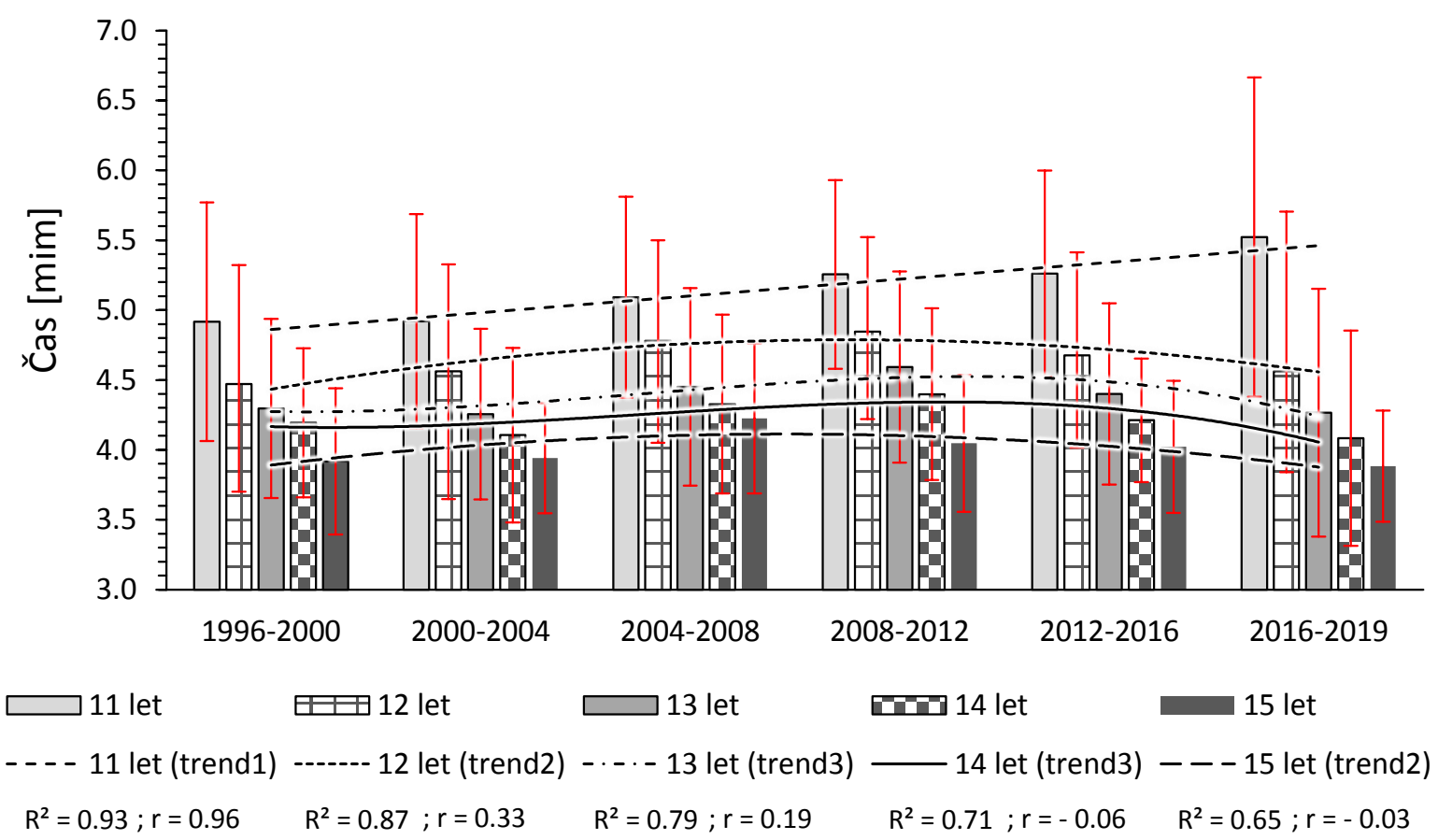

Legenda: Chybové úsečky představují interval hodnot aritmetický průměr \pm směrodatná odchylka.

trend1 regresní závislost vyjádřená polynomem 1. řádu (přímka)

trend2 regresní závislost vyjádřená polynomem 2. řádu (parabola)

trend3 regresní závislost vyjádřená polyno mem 3. řádu

$R^{2} \quad$ koeficient determinace regresního modelu

$r \quad$ Pearsonův korelační koeficient (těsnost vztahu mezi školním ročníkem a výkonem v dané věkové

Zdroj: Vlastni skupině)

Fig. 2: Běh na 1000 m-vývoj běžecké střednědobé vytrvalostní schopnosti

Z analýzy výkonů $\mathrm{v}$ motorickém testu běh na $1000 \mathrm{~m}$ jsme zaznamenali na základě Pearsonova korelačního koeficientu negativní trend vývoje výkonnosti u jedenáctiletých chlapců, který potvrzuje i statistická analýza významnosti rozdílů hodnot (viz Tab. 2). Ostatní věkové kategorie chlapců vykazují nulový trend vývoje výkonosti v běžecké střednědobé vytrvalostní schopnosti.

\subsection{Sed-leh opakovaně}

V motorickém testu sed-leh opakovaně indikátoru dynamické vytrvalostní schopnosti břišního svalstva a bedrokyčlostehenních flexorů je patrné zlepšení sohledem na narůstající chronologický věk v průběhu celého sledovaného období (viz Obr. 3 - Fig. 3). Výraznější zlepšení výkonnosti v tomto testu je patrné mezi 11letými a 12letými chlapci ze začátku sledovaného období a mezi 12letými a 13letými chlapci ke konci sledovaného období. 


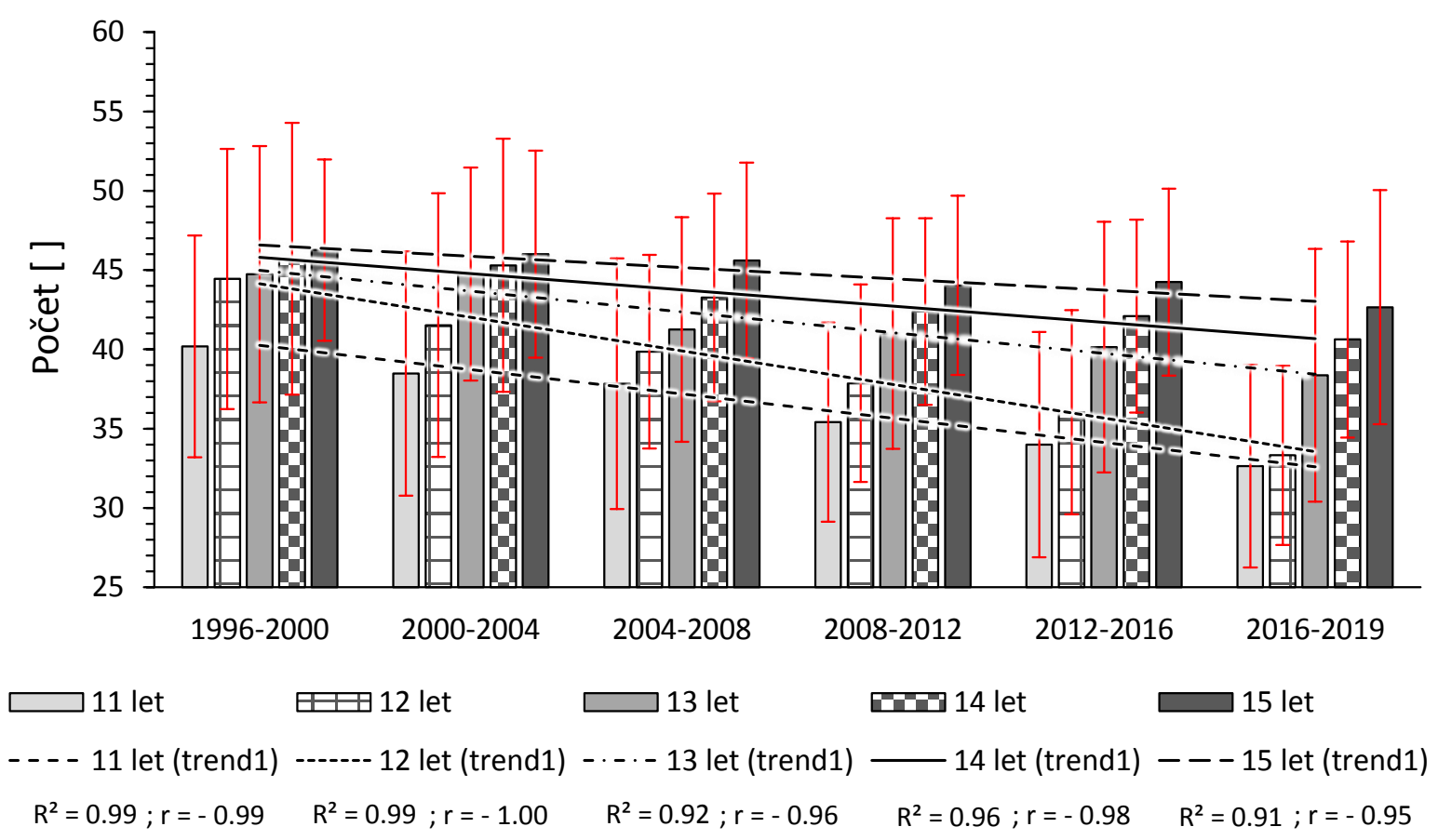

Legenda Chybové úsečky představují interval hodnot aritmetický průměr \pm směrodatná odchylka.

trend1 regresní závislost vyjádřená polynomem 1. řádu (př́ímka)

$R^{2} \quad$ koeficient determinace regresního modelu

$r \quad$ Pearsonův korelační koeficient (těsnost vztahu mezi školním ročníkem a výkonem v dané věkové

Zdroj: Vlastn skupině)

Fig. 3: Sed-leh opakovaně - vývoj dynamické vytrvalostní schopnosti břišního svalstva a bedrokyčlostehennich flexorù

Z analýzy výkonů v motorickém testu sed-leh opakovaně jsme zaznamenali na základě Pearsonova korelačního koeficientu negativní trend vývoje výkonnosti u chlapců všech věkových kategorií. Tento trend potvrzuje statistická a věcná významnost u jedenáctiletých až třináctiletých chlapců a statistická významnost u čtrnáctiletých chlapců (viz Tab. 2).

\subsection{Skok daleký}

V motorickém testu skok daleký indikátoru rychlostně silové schopnosti dolních končetin je patrné zlepšení s ohledem na narůstající chronologický věk u jedenáctiletých až čtrnáctiletých chlapců v průběhu celého sledovaného období a u patnáctiletých chlapců do roku 2016 (viz Obr. 4 - Fig. 4). Výraznější zlepšení výkonnosti v tomto testu je možné pozorovat mezi třináctiletými a čtrnáctiletými chlapci. Naopak stagnaci růstu výkonnosti pozorujeme mezi čtrnáctiletými a patnáctiletými chlapci. 


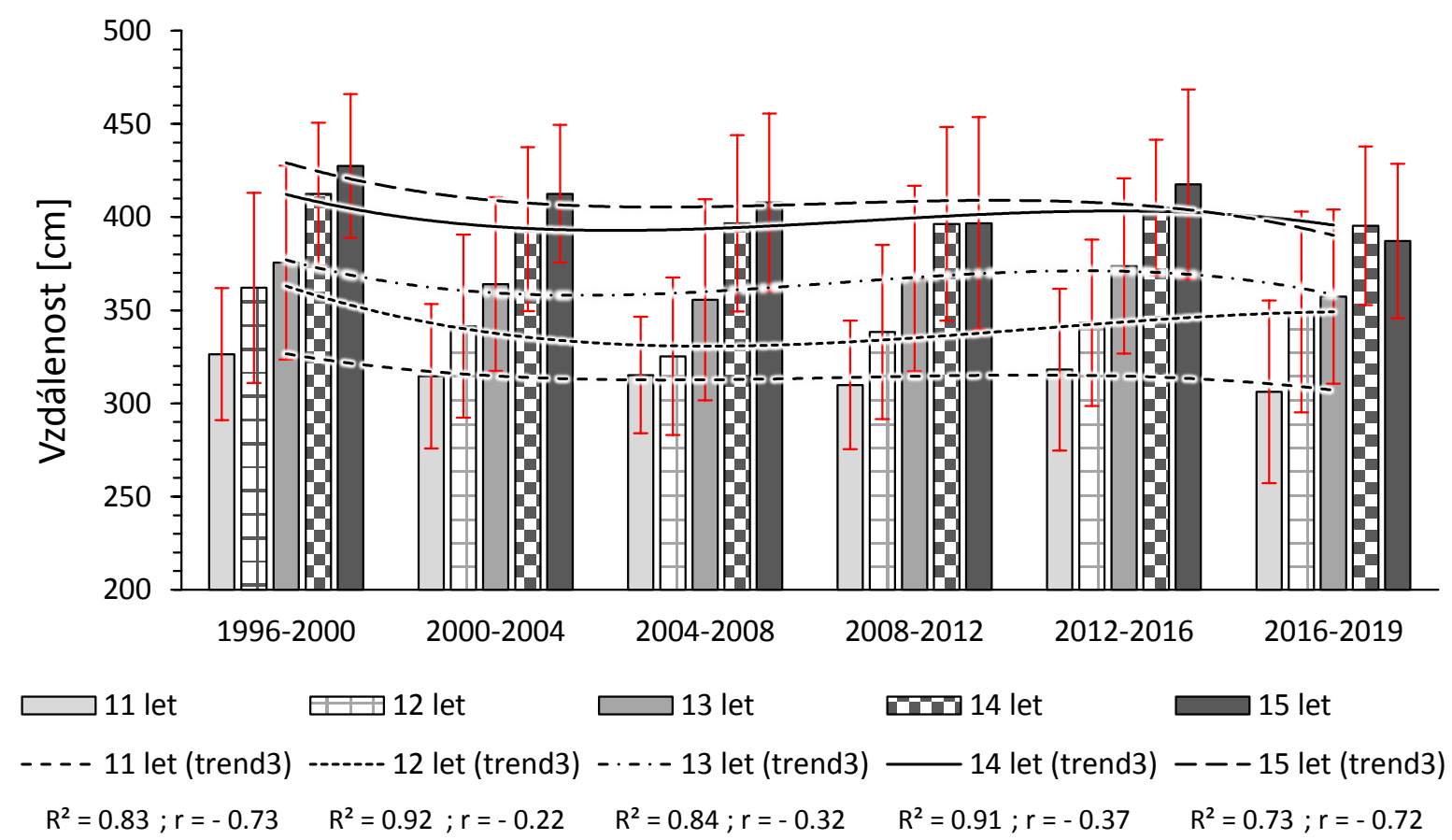

Legenda: Chybové úsečky představují interval hodnot aritmetický průměr \pm směrodatná odchylka.

trend3 regresní závislost vyjádřená polynomem 3. řádu

$R^{2} \quad$ koeficient determinace regresního modelu

$r \quad$ Pearsonův korelační koeficient (těsnost vztahu mezi školním ročníkem a výkonem v dané věkové

Zdroj: Vlastní skupině)

Fig. 4: Skok daleký - vývoj rychlostně silové schopnosti dolnich končetin

$\mathrm{Z}$ analýzy výkonů $\mathrm{v}$ motorickém testu skok daleký jsme zaznamenali na základě Pearsonova korelačního koeficientu kolísavý trend vývoje výkonnosti u třináctiletých a čtrnáctiletých chlapců. U jedenáctiletých a patnáctiletých chlapců pozorujeme trend s mírnou sestupnou tendencí ke konci sledovaného období, kterou u patnáctiletých chlapců potvrzuje i věcná významnost rozdílů hodnot (viz Tab. 2). Výkonnost dvanáctiletých chlapců vykazuje trend s mírnou vzestupnou tendencí, kterou potvrzuje statistická významnost rozdílů hodnot.

\subsection{Trojskok snožmo z místa}

V motorickém testu trojskok snožmo z místa indikátoru explozivně silové schopnosti dolních končetin je patrné zlepšení $s$ ohledem na narůstající chronologický věk v průběhu celého sledovaného období (viz Obr. 5 - Fig. 5). Výraznějš́ zlepšení výkonnosti v tomto testu je možné pozorovat mezi 13letými a 14letými chlapci. 


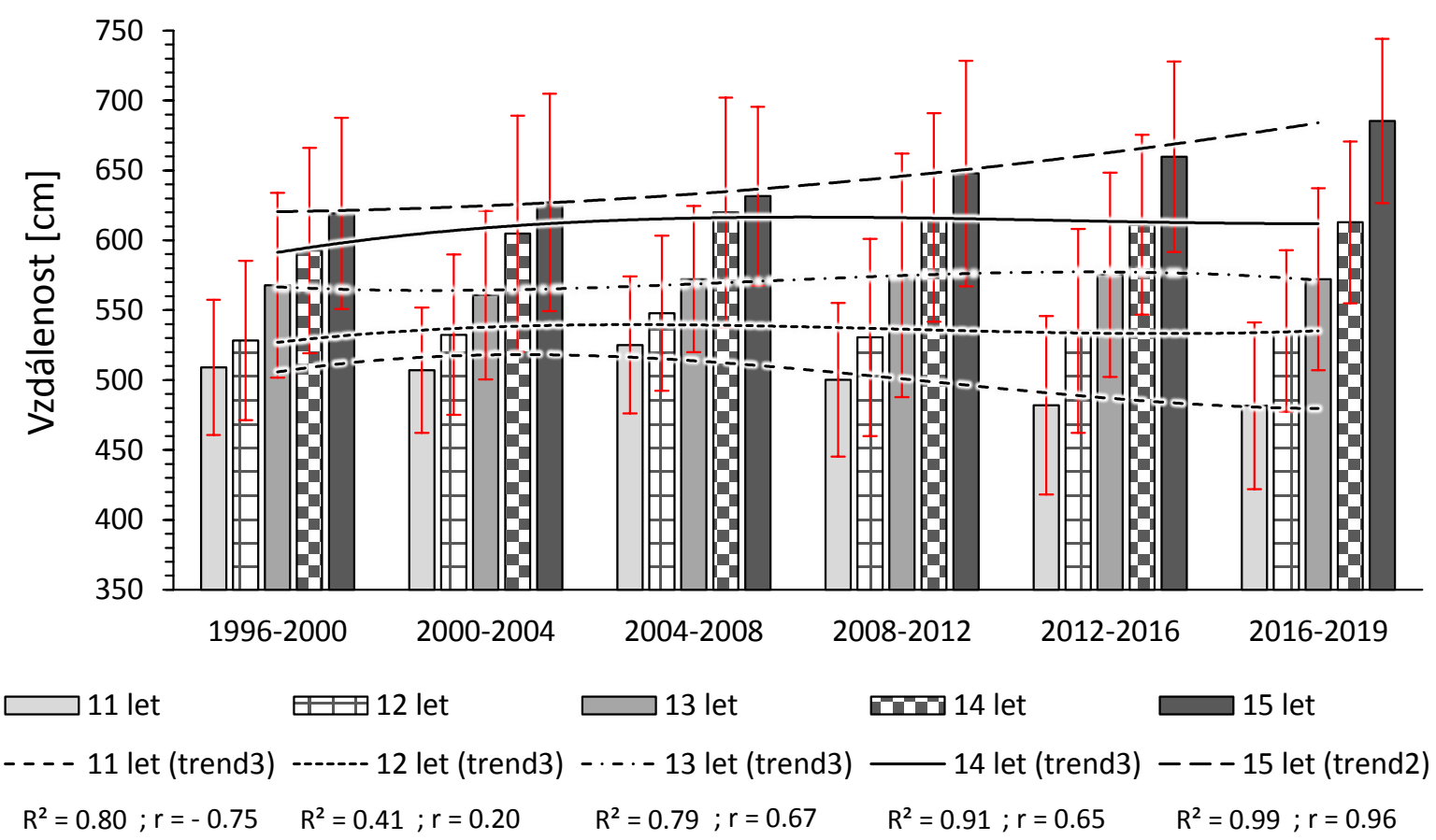

Legenda: Chybové úsečky představují interval hodnot aritmetický průměr \pm směrodatná odchylka.

trend2 regresní závislost vyjádřená polynomem 2. řádu (parabola)

trend3 regresní závislost vyjádřená polynomem 3. řádu

$R^{2} \quad$ koeficient determinace regresního modelu

$r \quad$ Pearsonův korelační koeficient (těsnost vztahu mezi školním ročníkem a výkonem v dané věkové Zdroj: Vlastní skupině)

Fig. 5: Trojskok snožmo z místa - vývoj explozivně silové schopnosti dolních končetin

Z analýzy výkonů v motorickém testu trojskok snožmo z místa jsme zaznamenali na základě Pearsonova korelačního koeficientu negativní trend vývoje výkonnosti u jedenáctiletých chlapců, který potvrzuje statistická i věcná analýza významnosti rozdílů hodnot (viz Tab. 2). Dvanáctiletí až čtrnáctiletí chlapci vykazují nulový trend v explozivně silové schopnosti dolních končetin. U patnáctiletých chlapců pozorujeme pozitivní trend vývoje výkonnosti, který je výraznější ke konci sledovaného období. Tento trend potvrzuje průměrné i maximální Cohenovo $d$ (viz Tab. 2).

\subsection{Shyby opakovaně}

V motorickém testu shyby opakovaně indikátoru dynamické silové schopnosti horních končetin je patrné zlepšení s ohledem na narůstající chronologický věk u jedenáctiletých až čtrnáctiletých chlapců v průběhu celého sledovaného období a u patnáctiletých chlapců do roku 2016 (viz Obr. 6 - Fig. 6). 


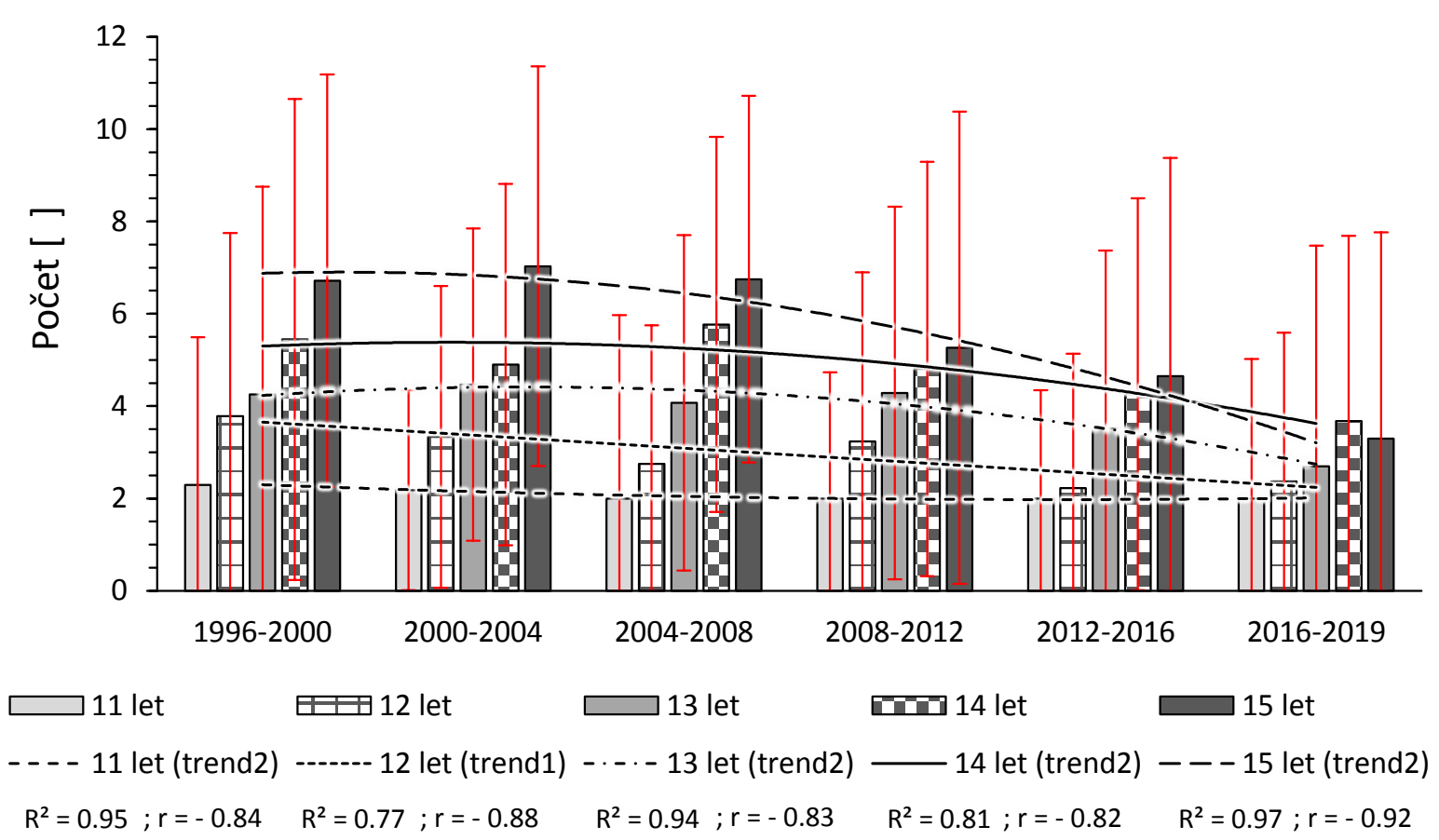

Legenda: Chybové úsečky představují interval hodnot aritmetický průměr \pm směrodatná odchylka.

trend1 regresní závislost vyjádřená polynomem 1. řádu (přímka)

trend2 regresní závislost vyjádřená polynomem 2. ř́a (parabola)

$R^{2} \quad$ koeficient determinace regresního modelu

$r \quad$ Pearsonův korelační koeficient (těsnost vztahu mezi školním ročníkem a výkonem v dané věkové

Zdroj: Vlastni skupině)

Fig. 6: Shyby opakovaně - vývoj dynamické silové schopnosti horních končetin

Při analýze dat jsme zaznamenali velké směrodatné odchylky ve výkonech chlapců. Přestože je počet realizovaných shybů v řádu jednotek, lze sledovat negativní trend vývoje výkonnosti. Tento trend potvrzuje i maximální Cohenovo $d$ u patnáctiletých chlapců (viz Tab. 2).

\section{Diskuze}

Často se řeší otázka, zda tělesná zdatnost dětí v posledních desetiletích klesá či stoupá. V odborné literatuře převládá názor, že tělesná zdatnost dětí stále klesá a současně úroveň somatických parametrů stále stoupá (negativně u tělesné hmotnosti a množství podkožního tuku). Vzájemné porovnání výsledků různých studií je komplikováno různorodostí testových baterií. Testová baterie použitá $\mathrm{v}$ našem výzkumu je heterogenní a to nás limituje $\mathrm{v}$ komparaci $\mathrm{s}$ jinými výzkumy.

Při komparaci běžeckých rychlostních schopností chlapců potvrzujeme závěry podobných studií Pavlík a Klárová [25], Kopecký [14, 15], Kuprová [19] a Przeweda a Dobosz [27], které vykazují nulový vývoj této běžecké schopnosti.

Vytrvalostní schopnost je pohybová schopnost provádět a udržovat dlouhodobou pohybovou činnost a schopnost překonávat únavu [22]. Aerobní zdatnost je pokládána za klíčovou složku tělesné zdatnosti potřebnou $\mathrm{v}$ každodenním životě. Dostatečná úroveň aerobní zdatnosti redukuje rizika kardiovaskulárních onemocnění, obezity, cukrovky a dalších zdravotních problémů $\mathrm{v}$ dospělosti. Jedinci s vyšší aerobní kapacitou lépe snáší vysoký stres přicházející z vnějšího prostředí $[3,33,34]$. Vědecké $[4,29,35,36]$ i populárně naučné články upozorňují na snižující se úroveň aerobní zdatnosti. Také naše studie toto potvrzuje pro 11leté chlapce a je v souladu se studiemi autorů: Raczek [28], Watanabe et al. [36], Dollmann et al. [10], 
Pavlík a Klárová [25] či Tomkinson et al. [33] (který analyzoval 55 studií) a dále se studiemi autorů Bunc et al. [4], Przeweda a Dobosz [27], Reed et al. [29], Tomkinson a Olds [35] a Watanabe a Yamamoto [36]. U vytrvalostních aktivit je obtížná motivace i schopnost překonávat únavu. Z hodin školní tělesné výchovy se vytrácejí vytrvalostní běhy, nebot' jsou mezi mládeží nepopulární. Při opakovaném začleňování těchto běhů do výuky se setkáváme $\mathrm{s}$ naprostou ignorací dětí, která může vést až k uvolňování z výuky tělesné výchovy.

Dospělá populace si často stěžuje na bolesti zad, což je často způsobeno nedostatečně vyvinutým břišním svalstvem [1]. Tento jev se projevuje u stále mladších kategorií. Bohužel to potvrzují i výsledky motorického testu sed-leh opakovaně, indikátoru dynamické vytrvalostní schopnosti břišního svalstva a bedrokyčlostehenních flexorů 11-15letých chlapců z Lomnice nad Popelkou.

K hodnocení motorické výkonnosti dětí školního věku je často používán test skok daleký $\mathrm{z}$ místa. Při porovnání výsledků v tomto testu zaznamenali vzestup výkonnosti autoři různých výzkumů [24, 23, 20]. Naopak Kopecký [14, 15], Przeweda a Dobosz [27], Kopecký a Přidalová [16], Kuprová [19] tvrdí, že pozitivní sekulární trend explozivně silových schopností dolních končetin 20. stolení je pozastaven. Pro sledování změn motorické výkonnosti chlapců z Lomnice nad Popelkou jsme měli k dispozici test skok daleký jako indikátor rychlostně silové schopnosti dolních končetin a test trojskok snožmo z místa jako indikátor explozivně silové schopnosti dolních končetin. V testu skok daleký pozorujeme kolísavou až sestupující úroveň motorické výkonnosti s výjimkou 12letých chlapců. Uvědomujeme si, že tento test je negativně ovlivněn běžeckou částí, nekoordinovanými pohyby i klátivou chůzí. V testu trojskok snožmo z místa jsme zaznamenali nulový trend vývoje výkonnosti s výjimkou 15etých chlapců a přikláníme se k názoru pozastavení pozitivního sekulárního trendu explozivně silové schopnosti dolních končetin i přesto, že výkonnost $\mathrm{v}$ tomto testu je ovlivněny pozitivním sekulárním trendem somatických parametrů (nárůstem hodnot).

Motorický test shyby ( $\mathrm{v}$ různých variantách) není tak často zařazován ani oblíben mezi veřejností. Důvodů může být několik. Málokdo v každodenním životě přijde do styku s tím, že by byl nucen udělat shyb. Ani při záměrné pohybové činnosti tento cvik $s$ takovou samozřjmostí, jako je např́íklad běh, skok a hod, neprovozujeme. Většinou ani „podobným“ aktivitám (např́klad: šplh) se nedostává taková popularita. V našem výzkumu jsme zaznamenali pokles dynamické silové schopnosti horních končetin chlapců. Ovlivněno to může být i narůstající tělesnou hmotností populace. Čím je tělesná hmotnost vyšší, tím více dynamické silové schopnosti horních končetin potřebujeme k zvednutí vlastního těla [19]. Tuto korelaci nemůžeme v našem výzkumu prokázat, jelikož měření somatických parametrů nebylo realizováno.

Pro prožití kvalitního života s minimem civilizačních chorob je zapotřebí, aby si populace již v dětském věku vypěstovala dobré životní návyky, správnou životosprávou a dostatečně pozitivní vztah k pohybové aktivitě, kterou bude dodržovat po celý život.

\section{Závěr}

Předložená studie se zaměřila na změny v motorické výkonnosti chlapců staršího školního věku. Pro stanovení úrovně tělesné zdatnosti chlapců 2 . stupně základní školy z Lomnice nad Popelkou byla použita neformální testové baterie šesti motorických testů v časovém úseku dvaceti dvou let (školní roky 1996/1997 - 2018/2019). Unikátnost výzkumu je v dlouhodobém sledování motorické výkonnosti a evidenci získaných dat chlapců na dané škole jedním examinátorem. 
Z vývoje motorické výkonnosti vyplývá, že u dynamické silové schopnosti horních končetin u dynamické vytrvalostní schopnosti břišního svalstva a bedrokyčlostehenních flexorů i částečně u rychlostně silové schopnosti dolních končetin dochází $\mathrm{k}$ poklesu výkonnosti u všech věkových kategorií chlapců. V indikátoru explozivně silové schopnosti dolních končetin jsme zaznamenali zvýšení výkonnosti u patnáctiletých chlapců. Ostatní věkové kategorie vykazují nulový až negativní trend vývoje výkonnosti. V běžecké rychlostní schopnosti i v běžecké střednědobé vytrvalostní schopnosti pozorujeme nezměněný vývoj výkonnosti chlapců. Výjimkou jsou jedenáctiletí chlapci, jejichž výkonnost v běžecké střednědobé vytrvalosti poukazuje na snižující se úroveň.

Získané výsledky poukazují na nezměněnou až snižující se úroveň motorické výkonnosti chlapců. Motorická výkonnost je důležitým prvkem tělesné zdatnosti a úroveň tělesné zdatnosti má př́mý vliv na kvalitu života. Tělesnou zdatnost můžeme pozitivně ovlivnit vykonáváním přiměřené pohybové aktivity. Vzhledem $\mathrm{k}$ tomu, že tělesná zdatnost je důležitým činitelem zdraví v dospělém věku, je velmi žádoucí naučit děti, jak jí dlouhodobě zdokonalovat a udržovat.

Sledování změn v motorické výkonnosti dětí považujeme za velmi důležité. I ty nejmenší změny v motorické výkonnosti dětí jsou odrazem různých odchylek v životním stylu, ve vlivu vnějšího prostředí a v pohybové aktivitě i inaktivitě dětí. V současné moderní době, světě moderních technologií, mobilitě společnosti a snadno dostupných atraktivních aktivit pro děti, mládež i dospělé je důležité být přiměřeně pohybově aktivní a tím pozitivně ovlivňovat své zdraví po celý život.

\section{Literatura}

[1] BAJZÍKOVÁ, J.: Balanční pomůcky nejen ke zlepšení stability, ale i kondice. Liberec: Technická univerzita v Liberci, 2014.

[2] BUNC, V.: Pojetí tělesné zdatnosti a jejích složek. Tělesná výchova a sport mládeže. 1995, 61(5).

[3] BUNC, V.: Standards of cardiovascular fitness in Czech children and youth. In D. Milanovic \& F. Prot (Eds.), KINESIOLOGY NEW PERSPECTIVES - 3rd. International Scientific Conference: Proceeding Book. Opatija. Croatia. September 25-29. 2002, pp 436-439. Zagreb: University of Zagreb.

[4] BUNC, V.: Tělesné složení, aerobní zdatnost a tělesná výkonnost českých dětí. In A. Suchomel \& M. Volf (Eds.), Tělesná výchova a sport 2004, Liberec-Euroregion Nisa: Sborník př́spěvků z mezinárodní vědecké conference. Liberec 24.-25. 6. 2004, pp. 12 18. Liberec: Technická univerzita v Liberci.

[5] ČELIKOVSKÝ, S.: Antropomotorika pro studující tělesnou výchovu, $3^{\text {rd }}$ ed. Praha: Státní pedagogické nakladatelství, 1990.

[6] CHYTRÁČKOVÁ, J.: UNIFITTEST (6-60). Přiručka pro manuální a počitačové hodnoceni základni motorické výkonnosti a vybraných charakteristik tělesné stavby mládeže a dospélých v České republice, $1^{\text {st }}$ ed. Praha: FTVS UK, 2002.

[7] COHEN, J.: Statistical power analysis for the behavioral science, $2^{\text {nd }}$ ed. Hillsdale, NJ: Erlbaum, 1988.

[8] COOPER, I.: FITNESSGRAM/ACTIVITYGRAM. Test administration manual, $4^{\text {th }}$ ed. Champaign IL: Human Kinetics, 2007. 
[9] COUNCIL OF EUROPE \& COMMITTEE FOR THE DEVELOPMENT OF SPORT: EUROFIT: European test of physical fitness, $1^{\text {st }}$ ed. Rome: Edigraf Editoriale Grafica, 1988.

[10] DOLLMAN, J.; OLDS, T.; NORTON, K.; STUART, D.: The Evolution of Fitness and Fatness in 10-11-Year-Old Australian Schoolchildren: Changes in Distributional Characteristics between 1985 and 1997. Pediatric Exercise Science. 1999, 11(19), pp. 108-109. DOI: $10.1123 /$ pes.11.2.108

[11] INDARES.COM. International Database for Research and Educational Support. 2020. Available from WWW: http://indares.com/

[12] JEŽKOVÁ, M.: Změny v motorické výkonnosti dětí školního věku v Lomnici nad Popelkou. Liberec: Technická univerzita v Liberci, 2017.

[13] KASA, J.: Športová kinantropológia - Terminologický a výkladový slovník. Bratislava: SVSTVŠ a FTVŠ UK, 2001.

[14] KOPECKÝ, M.: Tělesný rozvoj a motorická výkonnost 11-15letých chlapců v olomouckém regionu. In A. Suchomel \& M. Volf (Eds.), Tělesná výchova a sport 2004, Liberec - Euroregion Nisa: Sbornik př́spěvků z mezinárodní vědecké conference. Liberec 24.-25. 6. 2004, pp. 190-200. Liberec: Technická univerzita v Liberci.

[15] KOPECKÝ, M.: The secular trend in the somatic development and motoric performance of boys in the Olomouc region within the last 36 years. Acta Gymnica. 2006, 36(3), pp. 55-64.

[16] KOPECKÝ, M.; PŘIDALOVÁ, M.: The Secular Trend in the Somatic Development and Motor Performance of 7-15Year Old Girls. Medicina Sportiva. 2008, 12(3), pp. 7885. DOI: $\underline{10.2478 / \mathrm{v} 10036-008-0016-8}$

[17] KUPR, J.: Vztah pohybové aktivity ke komponentám tělesné zdatnosti u dètí školního věku. Brno: Masarykova Univerzita, 2015.

[18] KUPROVÁ, K.: Pohyb v zimním prostředi - skitouring, sněžnice. Liberec: Technická univerzita v Liberci, 2014.

[19] KUPROVÁ, K.: Sekulární trendy tělesné zdatnosti u dětí školního věku z libereckého regionu. Praha: Univerzita Karlova, 2015.

[20] MALINA, R. M.; BOUCHARD, C.; BAR-OR, O.: Growth, maturation and physical activity, $2^{\text {nd }}$ ed. Champaign IL: Human Kinetics, 2004.

[21] MĚKOTA, K.; BLAHUŠ, P.: Motorické testy v tělesné výchově. Praha: Státní pedagogické nakladatelství, 1983.

[22] MĚKOTA, K.; NOVOSAD, J.: Motorické schopnosti. Olomouc: Univerzita Palackého v Olomouci, 2007.

[23] MORAVEC, R.: Telesný, funkčný rozvoj a pohybová výkonnost' 7-18-ročnej mládeže $v$ ČSFR. Bratislava: Slovšport, 1990.

[24] PÁVEK, F.: Tělesná výkonnost 7-19leté mládeže ČSSR. Praha: Olympia, 1977.

[25] PAVLÍK, J.; KLÁROVÁ, R.: Komparace motorické výkonnosti současné mladé populace s populací dětí a mládeže v 60. a 80. letech. In: Role tělesné výchovy a sportuv tranformujicích se zemích středoevropského region. Brno: Masarykova Univerzita, 2001, pp. 37-44. 
[26] PlOWMAN, S. A.; STERLING, Ch. L.; CORBIN, Ch. B.; MEREDITH, M. D.; WELK, G. J.; MORROW, J. R. Jr.: The history of FITNESSGRAM ${ }^{\circledR}$. Journal of Physical Activity and Health. 2006, 3(s2), S5-S20. DOI: 10.1123/jpah.3.s2.s5

[27] PRZEWEDA, R.; DOBOSZ, J.: Growth and physical fitness of Polish youths in two successive decades. Journal of Sports Medicine and Physical Fitness. 2003, 43(4), pp. 465-474.

[28] RACZEK, J.: Changes in motor fitness in the Polish school population (1965-1995). Kinesiologia Slovenica. 1997, 3(1), 30-34.

[29] REED, K. E.; WARBURTON, D. E. R.; WHITNEY, C. L.; McKAY, H. A.: Secular Changes in Shuttle-Run Performance: A 23-Year Retrospective Comparison of 9- to 11Year-Old Children. Pediatric Exercise Science. 2006, 18(9), pp. 364-373. DOI: $10.1123 /$ pes.18.3.364

[30] RUBÍN, L.; SUCHOMEL, A.; KUPR, J.: Aktuální možnosti hodnocení tělesné zdatnosti u jedinců školního věku. Česká Kinantropologie. 2014, 18(1), pp. 11-22.

[31] SAZKA: Sazka Olympijský víceboj. Odznak všestrannosti. 2020.

[32] SUCHOMEL, A.: Tělesně nezdatné dèti školniho věku (motorické hodnocení, hlavní činitelé výskytu, kondični programy). Liberec: Technická univerzita v Liberci, 2006.

[33] TOMKINSON, G. R.; LÉGER, L. A.; OLDS, T. S.; CAZORLA, G.: Secular Trends in the Performance of Children and Adolescents (1980-2000) An Analysis of 55 Studies of the 20m Shuttle Run Test in 11 Countries. Sports Medicine. 2003, 33(4), pp. 285300. DOI: $10.2165 / 00007256-200333040-00003$

[34] TOMKINSON, G. R.; OLDS, T. S. (eds.): Secular Changes in Aerobic Fitness Test Performance of Australasian Children and Adolescents. Medicine and Sport Science. Karger, 2007, Vol. 50, pp. 168-182. DOI: 10.1159/000101361

[35] TOMKINSON, G. R.; OLDS, T. S. (eds.): Secular Changes in Pediatric Aerobic Fitness Test Performance: The Global Picture. Medicine and Sport Science. Karger, 2007, Vol. 50, pp. 46-66. DOI: $\underline{10.1159 / 000101075}$

[36] WATANABE, T.; YAMAMOTO, Y.; MIYASHITA, M.; MUTOH, Y.: Secular change in running performance of Japanese adolescents: A longitudinal developmental study. American Journal of Human Biology. 1998, 10(6), pp. 765-779. DOI: $\underline{10.1002 /(S I C I) 1520-6300(1998) 10: 6<765:: A I D-A J H B 8>3.0 . C O ; 2-0}$

PhDr. Klára Kuprová, Ph.D.; Mgr. Martina Ježková; PhDr. Jaroslav Kupr, Ph.D.;

Mgr. Josef Čapek; Mgr. Václav Bittner, Ph.D. 


\section{Changes in Motor Performance of Boys Aged 11-15 Years BeTween SCHOOL YEARS 1996/1997 - 2018/2019}

The study evaluates changes in motor performance in older school-age boys at a primary school in Lomnice nad Popelkou. The development of motor performance is monitored in boys aged 11-15 years from non-sports classes on the basis of an informal test battery of six motor tests (run for $60 \mathrm{~m}$, run for $1000 \mathrm{~m}$, curl-up, long jump, triple jump from a place, pullups) in a period of twenty-two years (school years 1996/1997-2018/2019). A total of 1,863 boys of all ages participated in motor testing. The results indicate an unchanged to declining level of motor performance over the recorded time period for most of the tests used in all age groups.

\section{ÄNDERUNGEN DER MOTORLEISTUNG VON JUNGEN IM ALTER VON 11-15 ZWISCHEN SCHULJAHREN 1996/1997 - 2018/2019}

Die Studie bewertet Veränderungen der motorischen Leistung bei Jungen im höheren Schulalter an einer Grundschule in Lomnice nad Popelkou. Die Entwicklung der Motorleistung wird bei Jungen im Alter von 11 bis 15 Jahren aus nicht sportlichen Klassen anhand einer informellen Testbatterie mit sechs Motortests überwacht $(60 \mathrm{~m}$ laufen, $1000 \mathrm{~m}$ laufen, wiederholt sitzen, Weitsprung, Dreisprung von einem Ort aus, wiederholt drücken) in einem Zeitraum von zweiundzwanzig Jahren (Schuljahre 1996/1997 - 2018/2019). Insgesamt nahmen 1.863 Jungen jeden Alters an Motortests teil. Die Ergebnisse zeigen für die meisten in allen Altersgruppen verwendeten Tests eine unveränderte bis abnehmende motorische Leistung über den aufgezeichneten Zeitraum.

\section{ZMIANY OSIĄGÓW RUCHOWYCH CHŁOPCÓW W WIEKU 11-15 LAT MIĘDZY LATAMI SZKOLNYMI 1996/1997 - 2018/2019}

W pracy dokonano oceny zmian sprawności ruchowej starszych chłopców w wieku szkolnym ze szkoły podstawowej w Lomnicach nad Popelkou. Rozwój sprawności motorycznej jest monitorowany $\mathrm{u}$ chłopców $\mathrm{w}$ wieku 11-15 lat $\mathrm{z}$ zajęć pozasportowych na podstawie nieformalnej baterii testowej sześciu testów motorycznych (bieg $60 \mathrm{~m}$, bieg $1000 \mathrm{~m}$, wielokrotne siedzenie, skok $\mathrm{w}$ dal, trójskok $\mathrm{z}$ miejsca, wielokrotne pchanie) $\mathrm{w}$ okresie dwudziestu dwóch lat (lata szkolne 1996/1997 - 2018/2019). W testach motorycznych wzięło udział łącznie 1863 chłopców w każdym wieku. Wyniki wskazują na niezmieniony lub malejący poziom sprawności motorycznej w zarejestrowanym okresie dla większości testów stosowanych we wszystkich grupach wiekowych. 